\title{
The Effect of Reading and Writing Literacy in Improving the Quality of Teaching Materials
}

\author{
Merli Yuridha \\ Universitas Negeri Padang \\ E-Mail: Merliyuridha107@gmail.com
}

Literacy is one of the important aspects that we must know. Literacy from time to time has undergone many changes. According to (Alfin, 2018) in its development literacy must receive attention. Literacy is a basic skill that must be mastered by every individual. Attention to literacy to improve student learning abilities in the future. Literacy is widely included in subjects at school. One of them is learning Indonesian. One aspect of literacy contained in learning Indonesian. In practice, Indonesian Language Learning focuses on four aspects of skills that require teacher creativity to achieve good learning outcomes. These four aspects of skills are also needed to study other subjects. Every aspect of Indonesian language skills is interrelated with each other. For example, a person can speak because he is able to listen, or is skilled at reading, and writing. Likewise, a person who is skilled at writing, if he is skilled at listening, speaking, and reading. Each skill is interrelated with one another. (Novelti et al., 2018)

Good learning outcomes can not be separated from the process and good teaching materials. According to (Mulyadi et al., 2020) learning is a relationship between teachers and students to exchange ideas based on the experiences of students so that learning outcomes are achieved optimally. In the learning process, orientation is no longer centered on the teacher, but students are more required to be active. So that teachers are required to be able to have competencies that are able to direct students to easily understand the teaching material. Professional competence of a teacher by having these competencies, among others, can develop professionalism in a sustainable manner by taking reflective actions, and using ICT to communicate and develop themselves. This means that scientific publication training for teachers is a professional development in the form of work as a reflective action for professional teachers (Agusrida et al., 2020). Furthermore (Syahrul, 2020) explained that the development of sophisticated technology will test the existence of professional teachers with their ability to use digital-based media and learning resources. This is because ICT skills are a must for a teacher.

Learning Indonesian at every level of education starting from elementary school to the next level is oriented towards improving students' Indonesian language skills (Sucia et al., 2020). The increase in these abilities must be directly proportional to the increase in teaching materials. One way to improve the quality of teaching materials is to use learning media. Technology-based learning media can foster a positive attitude of students towards the material and the learning process. One of the media used in literacy is the electronic module. (Indriyani et al., 2018) explains that the learning module is very important in learning to write. The learning module developed is based on problem based learning (PBL) in line with the scientific approach and text-based learning. 
In learning Indonesian, the learning used is based on the text. (Indriyani et al., 2019) In learning Indonesian, the curriculum used is text-based. Several years later, to realize the vision and mission so that society can adapt to advances in knowledge and technology, the government issued a policy on the School Literacy Movement (GLS) and updated it with the National Literacy Movement (GLN). write text. This will facilitate the teacher in carrying out the teaching and learning process. In using this module, the role of literacy is also very influential.

\section{Referensi}

Agusrida, Atmazaki, Syahrul, R., \& Ermanto. (2020). Effectiveness of Online Scientific Publication Training Approach for Teacher's Professional Competence Development at Religious Training Centre in Padang. 504(ICoIE), 370-375. https://doi.org/10.2991/assehr.k.201209.251

Alfin, J. (2018). Membangun Budaya Literasi dalam Pembelajaran Bahasa Indonesia Menghadapai Era Revolusi Industri 4.0. PENTAS: Jurnal Ilmiah Pendidikan Bahasa Dan Sastra Indonesia, 4(2), 60-66. https://jurnal.univpgripalembang.ac.id/index.php/Prosidingpps/article/view/2511

Indriyani, V., Asri, Y., \& Ramadhan, S. (2018). Learning Module Design Writing Argumentative Text Based Problem-Based Learning. 263(Iclle), 194-200. https://doi.org/10.2991/iclle-18.2018.32

Indriyani, V., Zaim, M., Atmazaki, A., \& Ramadhan, S. (2019). Literasi Baca Tulis Dan Inovasi Kurikulum Bahasa. KEMBARA: Jurnal Keilmuan Bahasa, Sastra, Dan Pengajarannya, 5(1), 108. https://doi.org/10.22219/kembara.vol5.no1.108-118

Mulyadi, Syahrul, R., Atmazaki, \& Agustina. (2020). The Development of E-Modules Based on Adobe Flash for Indonesian Subjects at IAIN Bukittinggi. Journal of Physics: Conference Series, 1471(1). https://doi.org/10.1088/1742-6596/1471/1/012002

Novelti, N., Ramadhan, S., Ermanto, E., \& Agustina, A. (2018). Developing an Instructional Model Assisted Audio Visual Media. 263(Iclle), 111-116. https://doi.org/10.2991/iclle-18.2018.17

Sucia, Ramadhan, S., Asri, Y., Padang, N., \& Padang, N. (2020). Pengembangan Modul Elektronik Berbasis Discovery Learning dalam Menulis Teks Eksplanasi. 463, 63-69.

Syahrul, R. (2020). Efektifitas Pendekatan Diklat Publikasi Ilmiah Online Untuk Pengembangan Kompetensi Profesional Guru di Balai Diklat Agama Padang. 504(ICoIE), 370375. 